\title{
Purification and Characterization of an Extracellular Lipase Produced by Aspergillus oryzae ST11 as a Potential Catalyst for an Organic Synthesis
}

\author{
Pattarapon Paitaid,", Jirayu Buatong', \\ Souwalak Phongpaichit ${ }^{2}$ and Aran H-kittikun ${ }^{1}$ \\ ${ }^{I}$ Department of Industrial Biotechnology, Faculty of Agro-Industry, Prince of Songkla University, \\ Hat Yai, Songkhla 90110, Thailand \\ ${ }^{2}$ Department of Microbiology and Natural Products Center of Excellence, Faculty of Science, \\ Prince of Songkla University, Hat Yai, Songkhla 90110, Thailand
}

('Corresponding author's e-mail: aw_54321@hotmail.com)

Received: 1 July 2020, Revised: 5 May 2021, Accepted: 11 May 2021

\begin{abstract}
The lipase producing Aspergillus sp. ST11 was identified by molecular and morphological methods. The primers ITS1/ITS4 were used for amplifying the ITS region. It showed that the strain was grouped with Aspergillus oryzae and Aspergillus flavus (98\% bootstrap value). The colony morphology of Aspergillus sp. ST11 on malt extract agar and Czapek yeast agar showed a characteristic of $A$. oryzae. Therefore, it was identified as Aspergillus oryzae ST11. The lipase produced by the strain was purified and characterized. The purification steps involved precipitation with chilled acetone and separation by column chromatography, with HiTrap ${ }^{\circledR}$ Q HP and Toyopearl Butyl-650M, respectively. After purification, the lipase activity was increased 13 fold and with $7.9 \%$ yield. Its molecular mass was 25 $\mathrm{kDa}$. The purified lipase was stable at a $\mathrm{pH}$ between $5.0-8.0$ and had optimum activity at $\mathrm{pH} 7.5$. It was stable at $30{ }^{\circ} \mathrm{C}$ and had optimum activity at $37{ }^{\circ} \mathrm{C}$. Its activity was promoted in the presence of $\mathrm{Mg}^{2+}$ but it was greatly decreased in the presence of $\mathrm{Co}^{2+}, \mathrm{Cu}^{2+}, \mathrm{Hg}^{2+}$ and $\mathrm{Zn}^{2+}$. Surfactants (Triton X-100, Tween80, Tween-20, arabic gum, and sodium dodecyl sulfate) showed negative effects on lipase activity, while inhibitors (PMSF, EDTA, and $\beta$-mercaptoethanol) did not reduce the activity significantly. Polar solvents, such as methanol and ethanol, had much negative effect on lipase activity compared to non-polar solvents, such as hexane and isooctane. The concentrated lipase from A. oryzae ST11 was used to catalyze the transesterification and gave the highest bioconversion (90\%) after $24 \mathrm{~h}$.
\end{abstract}

Keywords: Aspergillus, Biodiesel, Characterization, Lipase, Purification

\section{Introduction}

Triacylglycerol hydrolases, or lipases (E.C. 3.1.1.3), are groups of hydrolytic enzymes that break down the molecules of triglycerides and release free fatty acids and glycerol. They are also able to synthesize ester compounds. Lipases are obtained from various sources of living organisms, including plants, animals, and microorganisms [1,2]. Most of the lipases used in the biotechnological application are from bacteria and fungi, which are cultivated in submerged and solid-state fermentation [3-5]. The prominent points of using microbial lipase for industrial application are stability, substrate specificity, and production cost. They are more stable compared to lipases derived from animals or plants. Moreover, microbial lipases could be produced in a large-scale process, which is very important to many industries such as pharmaceuticals, detergents, and food [6-8]. Among lipase-producing microorganisms, filamentous fungi have become the best source. They can produce an extracellular enzyme that is easy for harvest and purification compared to bacterial lipases [7]. Moreover, fungal lipases are easily produced in large-scale production, which is more attractive for industrial applications [9]. The utilization of lipases in biofuel production has drawn attention from researchers due to their ability to catalyze with a wide range of oils, including low-grade oil containing a high amount of free fatty acids [10]. Xiao et al. [11] reported biodiesel production using a whole-cell biocatalyst from Aspergillus niger, which gave a high biodiesel yield (> $90 \%$ ) after $72 \mathrm{~h}$. Li et al. [12] reported the utilization of Rhizopus oryzae lipase expressed in 
Pichia pastoris for enzymatic biodiesel production. Their study showed a high biodiesel production $(>90$ $\%)$ after $72 \mathrm{~h}$.

The development of polymerase chain reaction (PCR), DNA sequencing, and molecular techniques has become the standard discipline to identify unknown organisms [13]. The identification of fungal strains is very important for strain selection. The safety of fungal use has been a concern for many applications. Some fungi produce mycotoxins, which affect the health of both humans and animals. Aspergillus spp., such as A. niger, A. flavus, A. fumigatus and A. terreus, are known as mycotoxin producers. Hence, the identification of fungal strains at the species level with morphological and molecular techniques is required. The internal transcribed spacer (ITS) is amplified by using ITS1 and ITS4 primers [14]. Kantak et al. [15] identified the isolate JK-1 using ITS1 and ITS4 primers and found that this isolate belonged to Rhizopus oryzae. Durairaj et al. [16] isolated the pathogenic fungal strains from ginseng root rot. The ITS1 and ITS2 primers were used for amplifying ITS region and showed pathogenic strains such as Cladosporium, Ilyonectria liliigena, Neonectria sp., and Fusarium sp. However, some species of Aspergillus could not be distinguished by using the only molecular technique. Morphological study is required to reliably identify the species level of Aspergillus [14].

Lipases produced by living organisms have been extensively studied by the purification scheme to understand their characteristics. Generally, the common steps of lipase purification consist of ion-exchange, hydrophobic, and gel filtration chromatographies. The purification of lipase from Aspergillus sp. is normally started from the ammonium sulfate precipitation of crude lipase, followed by applying it to ion-exchange chromatography [17]. However, some studies have had a slightly different scheme for lipase purification, by using a hydrophobic interaction column after ammonium sulfate precipitation $[18,19]$.

This research aims to find the capability of an extracellular lipase produced by this fungus, which is expected to offer the flexibility of enzymatic use in many applications over the use of whole-cell biocatalyst that is widely studied. Moreover, with the versatility of lipase, it would be expected to apply it to a process that requires high specificity towards a substrate and give a high quality of product. To achieve this objective, the selected strain of lipase-producing fungus was identified and used to produce lipase by cultivating it in submerged fermentation. The produced extracellular lipase was then purified and characterized to study its properties. The concentrated crude lipase was used for biodiesel production to study the possibility of organic synthesis.

\section{Materials and methods}

\section{Substrates and chemicals}

Palm oil, rice bran oil, coconut oil, sunflower oil, soybean oil, corn oil, and olive oil were purchased from a local market. The metal ions; $\mathrm{FeCl}_{3}, \mathrm{CoCl}_{3}, \mathrm{CuCl}_{2}, \mathrm{MgCl}_{2}, \mathrm{HgCl}_{2}, \mathrm{CaCl}_{2}, \mathrm{ZnCl}_{2}, \mathrm{KCl}, \mathrm{NaCl}$ and $\mathrm{AlCl}_{3}$, and the surfactants; Triton X-100, Tween 80, Tween 20, gum arabic, and sodium dodecyl sulfate (SDS) were purchased from Analytical Univar Reagent (Auckland, New Zealand). The enzyme inhibitors: ethylenediaminetetraacetic acid (EDTA), phenylmethylsulfonyl fluoride (PMSF), and $\beta$ mercaptoethanol were purchased from Sigma-Aldrich (St. Louis, USA).

\section{Analytical methods}

\section{Lipase activity}

The hydrolytic activity of lipase was measured in a 2-phase system according to the modified colorimetric method [20], using palm oil as a substrate in isooctane. $0.1 \mathrm{~mL}$ of the crude enzyme was added to $0.5 \mathrm{~mL}$ of $10 \% \mathrm{w} / \mathrm{v}$ palm oil in isooctane. After that, the mixture was incubated in a Thermomixer (TAITEC, Japan) at $37^{\circ} \mathrm{C}$ and $1,200 \mathrm{rpm}$ for $30 \mathrm{~min}$. The reaction was eventually stopped by adding $0.15 \mathrm{~mL}$ of $6 \mathrm{~N} \mathrm{HCl} .0 .1 \mathrm{~mL}$ of the upper organic phase was withdrawn and mixed with 0.9 $\mathrm{mL}$ of iso-octane. The solution was then mixed thoroughly with $0.2 \mathrm{~mL}$ of cupric acetate solution. The upper phase was measured for absorbance at $715 \mathrm{~nm}$ using isooctane as a blank. Lipase activity was determined by measuring the amount of fatty acids liberated as palmitic acid. One unit of enzyme activity was defined as the enzyme necessary to release $1 \mu \mathrm{mol}$ of palmitic acid per min at the specified conditions [21].

\section{Protein determination}

The protein of the samples in the purification steps was determined using Folin-Ciocalteu reagent according to Lowry's method [22].

Analysis of biodiesel production using thin-layer chromatography with flame-ionized detector (TLC-FID analyzer) 
Transesterification products were analyzed by IATROSCAN'M MK-5 TLC-FID analyzer (Iatron Laboratories, Inc. Tokyo, Japan). The sample was spotted on the Chromarod-SIII. The spotted Chromarods were developed by the 2 -solvent system. The $1^{\text {st }}$ chamber contained a solvent mixture of nhexane/diethyl ether/formic acid (50:20:0.3 v/v/v), and the $2^{\text {nd }}$ chamber contained a solvent mixture between benzene/n-hexane $(1: 1 \mathrm{v} / \mathrm{v})$. The spotted Chromarods were developed in the $1^{\text {st }}$ chamber for 15 min and subsequently transferred to the $2^{\text {nd }}$ chamber with a development time of $30 \mathrm{~min}$. The Chromarods were dried in a hot air oven at $105{ }^{\circ} \mathrm{C}$ for $10 \mathrm{~min}$. The dried Chromarods were scanned by a TLC-FID analyzer $(2,000 \mathrm{~mL} / \mathrm{min}$ air flow rate, $160 \mathrm{~mL} / \mathrm{min}$ of $\mathrm{H} 2$ flow rate, and $30 \mathrm{~s} / \mathrm{scan}$ of scanning speed). The peak area ratio was calculated with i-ChromStar software. Biodiesel production was reported as the percentage of the area compared to all peak areas of transesterification reaction [23].

\section{Molecular and morphological identification}

Aspergillus sp. isolate ST11 was obtained from the stock culture of the Enzyme Laboratory, Department of Industrial Biotechnology, Faculty of Agro-Industry, Prince of Songkla University. Hat Yai, Thailand. The internal transcribed spacer (ITS) region was amplified using primers ITS1/ITS4 [24]. The universal primers used for fungal amplification were ITS1 (5'-TCC GTA GGT GAA CCT GCG G$\left.3^{\prime}\right)$ and ITS4 (5'-TCC TCC GCT TAT TGA TAT GC-3'). Reactions involved 1 cycle of initial denaturation at $94{ }^{\circ} \mathrm{C}$ for $5 \mathrm{~min}$, followed by 35 cycles with a denaturation step at $94{ }^{\circ} \mathrm{C}$ for $1 \mathrm{~min}$, an annealing step at $58{ }^{\circ} \mathrm{C}$ for $1 \mathrm{~min}$, and an extension step at $72{ }^{\circ} \mathrm{C}$ for $1 \mathrm{~min}$, followed by 1 cycle at $72{ }^{\circ} \mathrm{C}$ for 10 mins. The ClutalWin Bioedit was used for aligning the consensus sequence amplified by ITS1/ITS4 primers [25]. The sequence was then compared (BLAST) against the GenBank database. Phylogenetic analysis was performed using MEGA software version 6.0 [26] by applying a neighborjoining (NJ) method on ITS sequence.

For morphological identification, the isolate ST11 was cultured on malt extract agar (MEA) and Czapek yeast agar (CYA) and incubated at 25 and $37{ }^{\circ} \mathrm{C}$ for 7 days. The colony color and microscopic morphology were observed [14].

\section{Production and purification of lipase}

The fungal spore was inoculated on potato dextrose agar and incubated at $37^{\circ} \mathrm{C}$ for 5 days. The spores were collected and adjusted to $1 \times 10^{7}$ spore/mL using a hemacytometer, and $1 \mathrm{~mL}$ of inoculum was inoculated into the optimized medium $(100 \mathrm{~mL})$ containing $1 \%$ olive oil, $2 \%$ peptone, $0.2 \% \mathrm{NaNO}_{3}, 1 \%$ $\mathrm{KH}_{2} \mathrm{PO}_{4}, 0.05 \% \mathrm{MgSO}_{4}$, and $0.5 \%$ lactose $(\mathrm{w} / \mathrm{v})$, and the $\mathrm{pH}$ adjusted to 6.0 . The culture medium was shaken at $150 \mathrm{rpm}$ and $37{ }^{\circ} \mathrm{C}$ for 4 days. Purification of the lipase was carried out with the steps of solvent precipitation (chilled acetone), an anion-exchange column chromatography (HiTrap Q HP $5 \mathrm{~mL}$ ), and a hydrophobic column chromatography (Toyopearl Butyl-650M).

The culture broth was separated from the mycelium by filtration with Whatman no.1 filter paper. The crude enzyme was precipitated from the culture broth by adding 3 volumes of cold acetone per 1 volume of the culture broth and being kept at $4{ }^{\circ} \mathrm{C}$ overnight. The solution was centrifuged $(8,000 \mathrm{rpm}$ at $4{ }^{\circ} \mathrm{C}$ for $10 \mathrm{~min}$ ) and the precipitate was dissolved with a small amount of $50 \mathrm{mM}$ Tris-HCl buffer $\mathrm{pH} 7.5$ and transferred to a dialysis bag $(3,500 \mathrm{Da})$. The sample was dialyzed against the same buffer at $4{ }^{\circ} \mathrm{C}$ overnight. The expanded volume of the sample was reduced using the adsorption of carboxymethyl cellulose powder (CMC). The concentrated lipase was collected for purification and characterization.

The lipase solution $(2 \mathrm{~mL})$ was applied to a HiTrap Q HP column by using an ÄKTA Prime chromatography system (Amersham Pharmacia Biotechnique Group, Sweden). The process was carried out with 2 buffer systems $(50 \mathrm{mM}$ Tris- $\mathrm{HCl}$ buffer $\mathrm{pH} 7.5)$ that contained no $\mathrm{NaCl}$ and with $1 \mathrm{~N} \mathrm{NaCl}$. The concentration of $\mathrm{NaCl}$ was increased from $0-5,5-15$ and $15-100 \%$. All fractions were monitored for absorbance at $280 \mathrm{~nm}$ and lipase activity was assayed. The active fractions were combined and used for the next purification step.

The enzyme obtained from the anion exchange chromatography step was applied to the Toyopearl Butyl 650M column. The column was equilibrated with $50 \mathrm{mM}$ Tris- $\mathrm{HCl}$ buffer $\mathrm{pH} 7.5$ with $50 \%$ ammonium sulfate. After applying enzyme solution to the column, the column was washed with equilibrate buffer and the concentration of salt was gradually decreased from 50 to $0 \%$. The fractions showing absorbance $(280 \mathrm{~nm})$ were collected and the lipase activity was assayed. The active fractions were pooled and dialyzed against the same buffer without ammonium sulfate at $4{ }^{\circ} \mathrm{C}$ overnight and concentrated by adsorption with CMC. The concentrated enzyme solution was evaluated by sodium dodecyl sulfate-polyacrylamide gel electrophoresis (SDS-PAGE). The samples were mixed in sample buffer and boiled in the water bath at $90{ }^{\circ} \mathrm{C}$ for $10 \mathrm{~min}$. Samples were applied to a $5.0 \%$ gel system concentrator and a $10 \%$ separator. Electrophoresis was performed at $50 \mathrm{~V}$ for $30 \mathrm{~min}$ and $100 \mathrm{~V}$ for 60 
min. After electrophoresis, the separated proteins were stained with Coommassie Blue R-250 reagent. The molecular weight of the purified ST11 lipase was compared to the standard marker (Pink Plus Prestained Protein ladder with sizes ranging from $10-175 \mathrm{kDa}$ ).

\section{Characterization of purified lipase from Aspergillus oryzae ST11}

Effect of $\mathrm{pH}$ and $\mathrm{pH}$ stability

The optimum $\mathrm{pH}$ for lipase ST11 activity was studied; the lipase was prepared in different buffers with the same concentration $(50 \mathrm{mM})$ and was determined for activity at $37{ }^{\circ} \mathrm{C}$. The buffers used in the study were acetate buffer ( $\mathrm{pH} 4.0$ - 6.0), phosphate buffer ( $\mathrm{pH} 6.0$ - 7.0), and Tris-HCl buffer (pH 7.0-9.0). In the case of $\mathrm{pH}$ stability, the purified lipase was mixed with the above buffers $(1: 3, \mathrm{v} / \mathrm{v})$, and the sample was incubated at $30^{\circ} \mathrm{C}$ for $2 \mathrm{~h}$. The residual activity of the purified lipase ST11 was determined at $\mathrm{pH}$ 7.5.

\section{Effect of temperature and thermostability}

The purified lipase activity was assayed at temperatures ranging from $30-65^{\circ} \mathrm{C}$ in $50 \mathrm{mM}$ Tris$\mathrm{HCl}$ buffer, $\mathrm{pH}$ 7.5. For effect of temperature on lipase stability, the purified lipase was incubated at different temperatures from $30-65^{\circ} \mathrm{C}$ for $2 \mathrm{~h}$ before determining activity at $37{ }^{\circ} \mathrm{C}$.

\section{Effect of metal ions}

Different metal ions $\left(\mathrm{Fe}^{2+}, \mathrm{Co}^{2+}, \mathrm{Cu}^{2+}, \mathrm{Mg}^{2+}, \mathrm{Hg}^{2+}, \mathrm{Ca}^{2+}, \mathrm{Zn}^{2+}, \mathrm{K}^{+}, \mathrm{Na}^{+}\right.$and $\mathrm{Al}^{3+}$ ) were used for testing their effects on the activity of the purified ST11 lipase. The enzyme was added into the reaction mixture containing $50 \mathrm{mM}$ Tris- $\mathrm{HCl}$ buffer $\mathrm{pH} 7.5$ and metal ions at 1.0 and $10.0 \mathrm{mM}$. The reaction was carried out at $30{ }^{\circ} \mathrm{C}$ for $30 \mathrm{~min}$. The lipase activity was assayed and compared to the control without the addition of metal ions.

\section{Effect of inhibitors and surfactants}

Different inhibitors and surfactants were determined for their effects on the lipase ST11 activity. The purified ST11 lipase was incubated at $30^{\circ} \mathrm{C}$ for $30 \mathrm{~min}$ in $50 \mathrm{mM}$ Tris- $\mathrm{HCl}$ buffer $\mathrm{pH} 7.5$ containing different inhibitors $(1.0 \mathrm{mM})$ : $\beta$-mercaptoethanol, phenyl methyl sulphonyl fluoride (PMSF), and ethylene diamine tetra-acetic acid (EDTA), and surfactants $(1.0 \%$, w/v): gum arabic, Triton X-100, Tween 20, Tween 80, and sodium dodecyl sulfate (SDS). The lipase activity was assayed and compared to the control without the addition of inhibitors or surfactants.

\section{Effect of organic solvents}

The effects of different organic solvents (ethanol, methanol, acetone, ethyl acetate, isopropanol, xylene, toluene, isooctane, and hexane) on the lipase activity was determined. The organic solvent $(0.15 \mathrm{~mL})$ was added to purified lipase solution $(0.45 \mathrm{~mL})$ in a microcentrifuge tube. The mixture was incubated in a Thermomixer shaker (TAITEC, Japan) at $30^{\circ} \mathrm{C}$ and $500 \mathrm{rpm}$ for $1 \mathrm{~h}$. The lipase activity was then measured and compared to the control.

\section{Substrate specificity}

The substrate specificity of the purified ST11 lipase was studied by using different vegetable oils as a substrate, including palm oil, rice bran oil, coconut oil, sunflower oil, soybean oil, corn oil and olive oil. Each kind of oil was used to replace the palm oil in the reaction mixture for lipase activity determination using the cupric acetate method.

\section{Biodiesel production catalyzed by concentrated ST11 lipase}

The concentrated $A$. oryzae ST1 lipase $(100 \mu \mathrm{L})$ from the chilled acetone precipitation step was mixed with $2 \mathrm{~mL}$ of $10 \%$ palm oil in isooctane and methanol at a molar ratio of methanol/palm oil at 3:1. The reaction mixture was incubated at $37{ }^{\circ} \mathrm{C}$ in a Thermomixer with $1,200 \mathrm{rpm}$ for $24 \mathrm{~h}$. The sample $(50$ $\mu \mathrm{L})$ was withdrawn and mixed with isooctane $(50 \mu \mathrm{L})$. The biodiesel produced was analyzed by the TLCFID analyzer.

\section{Statistical analysis}

The experimental data were expressed as mean \pm standard deviation from triplicates. One-way analysis of variance (ANOVA) was carried out, and comparisons of means were done by Duncan's new multiple range tests, with a significance threshold $p<0.05$. Statistical analyses were performed with the statistical program SPSS (version 16.0 for Windows, SPSS Inc., Chicago, IL, USA). 


\section{Results and discussion}

Molecular and morphological identifications

According to neighbor-joining (NJ) phylogenetic tree analysis of the ITS sequence, Aspergillus sp. ST11 was grouped with $A$. flavus and $A$. oryzae (98\% bootstrap value). This strain showed sequence similarity to A. flavus UOA/HCPF 10017 (FJ878656) and A. oryzae A-4 (GU120193) with $100 \%$ (Figure 1). Molecular identification using ITS sequence cannot be used to differentiate $A$. flavus and $A$. oryzae. Therefore, the morphology of the strain ST11 on MEA and CYA was further investigated. For morphological identification, the strain ST11 grew well on CYA and MEA. The colony on CYA was yellow-green (Figures 2(a) - 2(d)) and the colony on MEA was olive green (Figures 2(e) - 2(h)). Conidiophores were $0.08-0.09 \mu \mathrm{m}$ in length, colorless, and roughened (Figures 3(a) and 3(b)). Conidia were $3.2-4.1 \mu \mathrm{m}$ in diameter, globose to the ellipsoidal, and had smooth walls (Figure 3(c)). The results from this study were well related to the morphology of the A. oryzae colony on CYA and MEA [14]. Therefore, the isolate ST11 was designated as A. oryzae ST11 using molecular identification based on ITS regions and morphological characters (GenBank accession number MK784896).

\section{Purification of lipase}

The purification table is summarized in Table 1. The yield of lipase after chilled acetone precipitation was $56 \%$, and there was a 7.7-fold increase in activity. The sample was then applied to the ÄKTA Prime chromatography system connected with a HiTrap Q HP column. It was found that $15 \%$ $\mathrm{NaCl}$ could elute the target enzyme from the column (Figure 4(a)). At this step, $28.9 \%$ of lipase yield and a 10.2-fold increase of activity were obtained. For Toyopearl Butyl-650M column chromatography, the active fractions were obtained after $50 \mathrm{mM}$ Tris- $\mathrm{HCl}$ buffer $\mathrm{pH} 7.5$ with $0.4 \%$ ammonium sulfate was applied to the column (Figure 4(b)). The yield of lipase at this step was $7.9 \%$, and the purification fold was 13.0. The decrease of the lipase yield after the lipase concentration step was similar to the study of Toida et al. [27] that reported a decrease of lipase yield of $A$. oryzae to $54 \%$ after ammonium sulfate precipitation and gave s yield of only $5.5 \%$ after the final purification step. Mehta et al. [18] studied the purification of lipase from A. fumigatus using Octyl Sepharose column chromatography (hydrophobic column) and found that the lipase yield was $11.03 \%$ and the purification fold was 6.96 .

The molecular mass of the purified lipase was determined by using the SDS-PAGE technique. The purity of the A. oryzae ST11 lipase was examined and confirmed with a single band of protein with 25 kDa molecular mass (Figure 5). The molecular mass of the lipase from A. oryzae ST11 in this study was similar to the size $(27 \mathrm{kDa})$ of lipase from $A$. oryzae isolated from waste cooking oily soil [28]. However, the study of Toida et al. [27] showed that the molecular mass of lipase from A. oryzae was $41 \mathrm{kDa}$. 


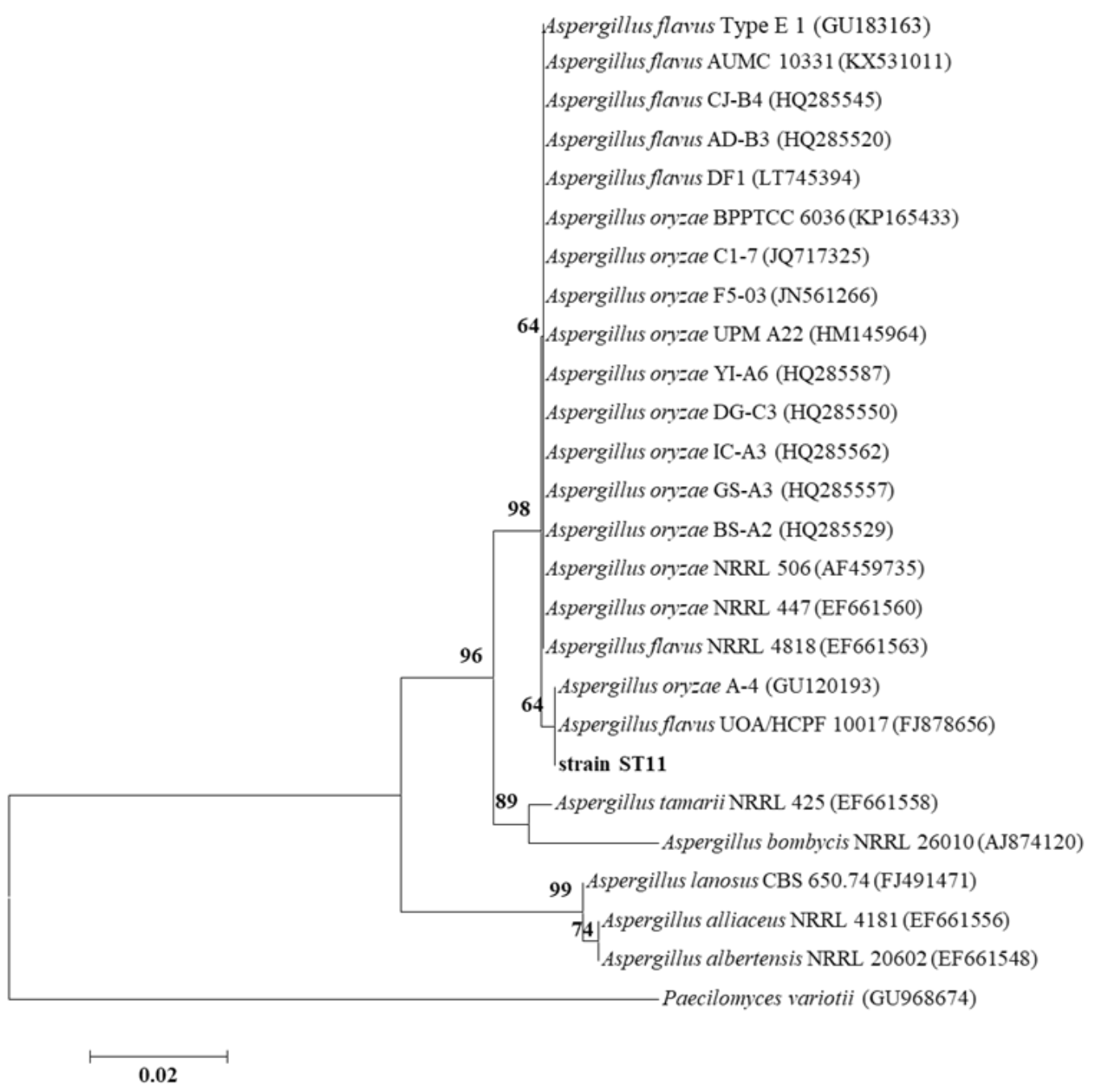

Figure 1 The Neighbor-joining phylogenetic tree obtained from ITS rDNA sequence analysis based on the Tamura Nei model, calculated using MEGA 6.0. The scale bar denotes 0.02 substitutions per position. Paecilimyces variotii was used as the root of tree. 

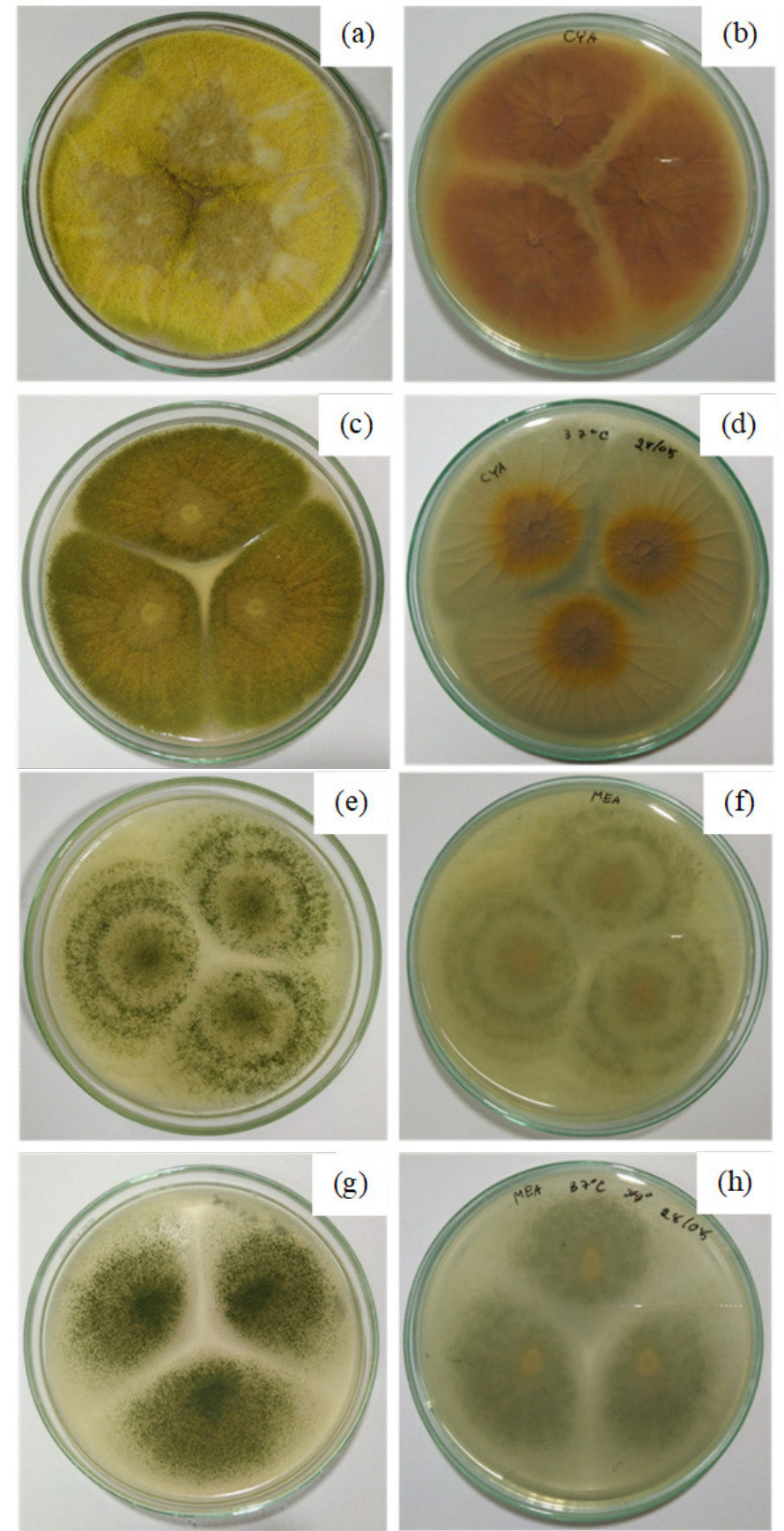

Figure 2 Colony morphology of Aspergillus sp. ST11 on Czapek's yeast agar at $25^{\circ} \mathrm{C}(\mathrm{a}, \mathrm{b})$ and $37{ }^{\circ} \mathrm{C}$ (c, d) and on malt extract agar at $25^{\circ} \mathrm{C}(\mathrm{e}, \mathrm{f})$ and $37^{\circ} \mathrm{C}(\mathrm{g}, \mathrm{h})$ for 7 days. 

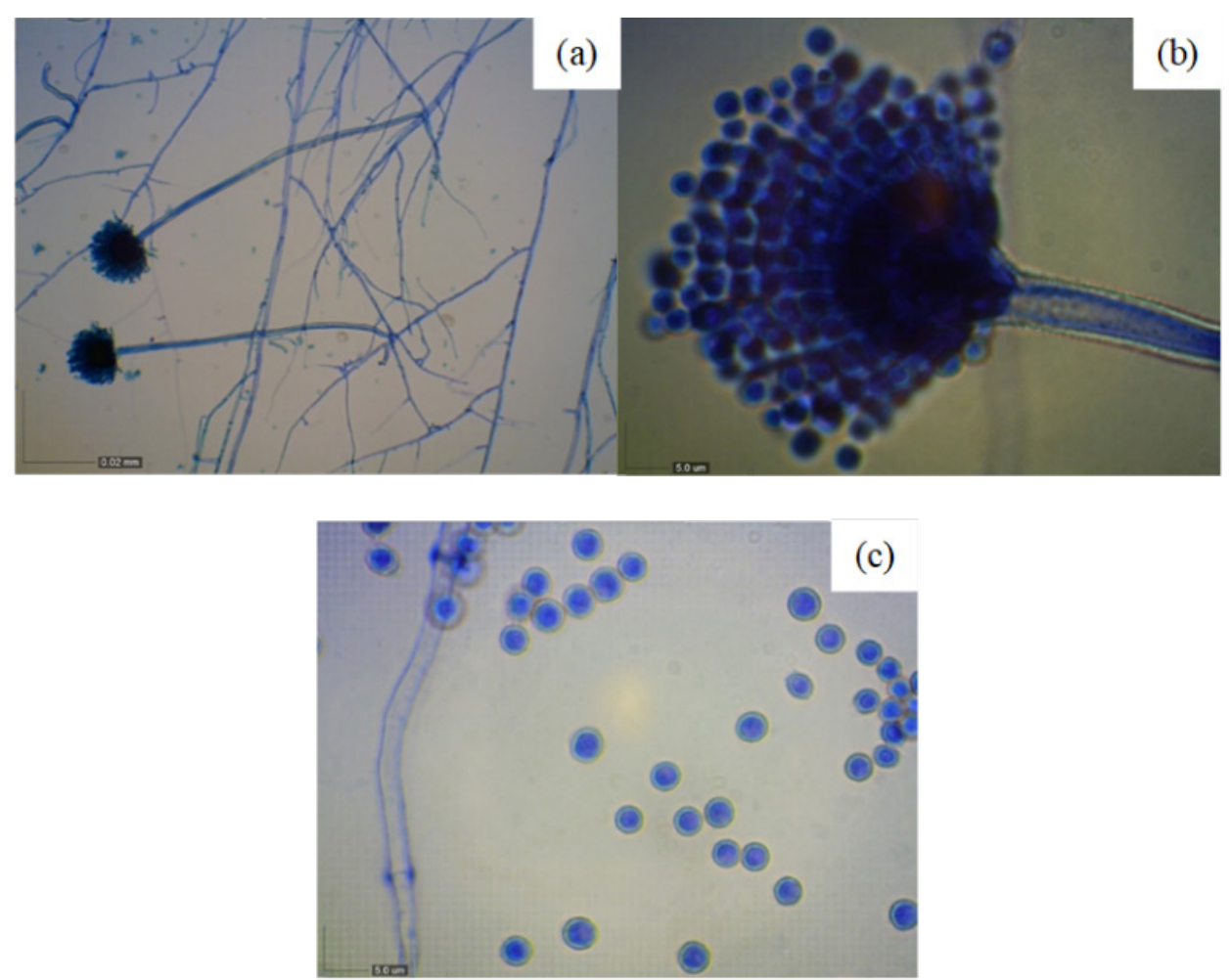

Figure 3 Conidiophores at $100 \times$ (a) and $400 \times$ (b), and conidia at $400 \times$ (c), of Aspergillus sp. ST11.

Table 1 Purification table of lipase from Aspergillus oryzae ST11.

\begin{tabular}{cccccc}
\hline Purification step & $\begin{array}{c}\text { Total } \\
\text { protein } \\
\text { (mg) }\end{array}$ & $\begin{array}{c}\text { Total } \\
\text { activity } \\
\text { (unit) }\end{array}$ & $\begin{array}{c}\text { Specific } \\
\text { activity } \\
\text { (U/mg) }\end{array}$ & $\begin{array}{c}\text { Yield } \\
\text { (\%) }\end{array}$ & $\begin{array}{c}\text { Purification } \\
\text { fold (fold) }\end{array}$ \\
\hline $\begin{array}{c}\text { Supernatant } \\
\text { Acetone precipitation }\end{array}$ & 1,300 & 16,000 & 12.3 & 100 & 1.0 \\
$\begin{array}{c}\text { Q-HP column } \\
\text { chromatography }\end{array}$ & 95 & 8,960 & 94.3 & 56 & 7.7 \\
$\begin{array}{c}\text { Butyl-Toyo pearl column } \\
\text { chromatography }\end{array}$ & 87 & 4,635 & 125.3 & 28.9 & 10.2 \\
\hline
\end{tabular}



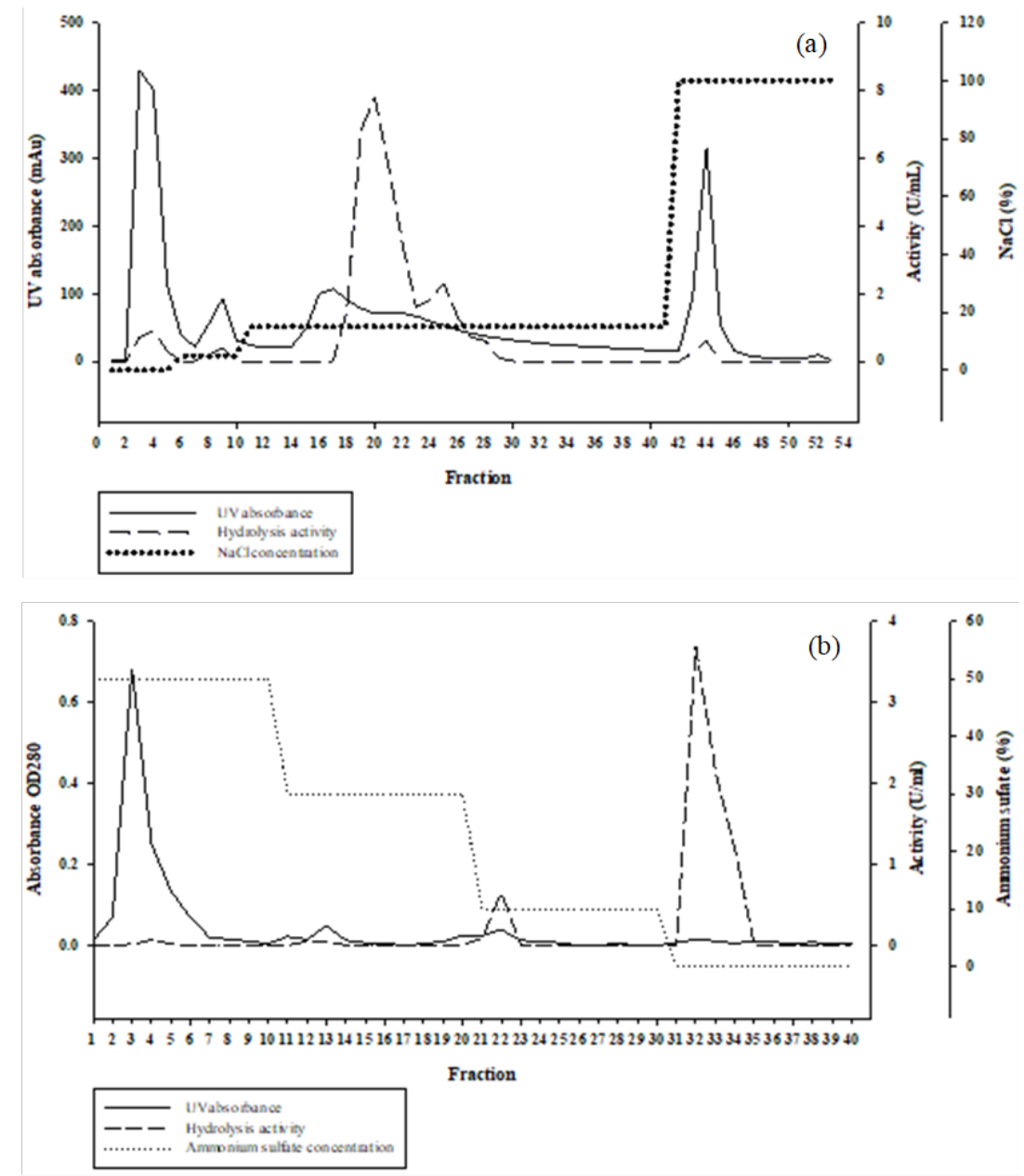

Figure 4 Purification of Aspergillus oryzae ST11 lipase carried out by ion exchange chromatography (a) and hydrophobic chromatography (b).

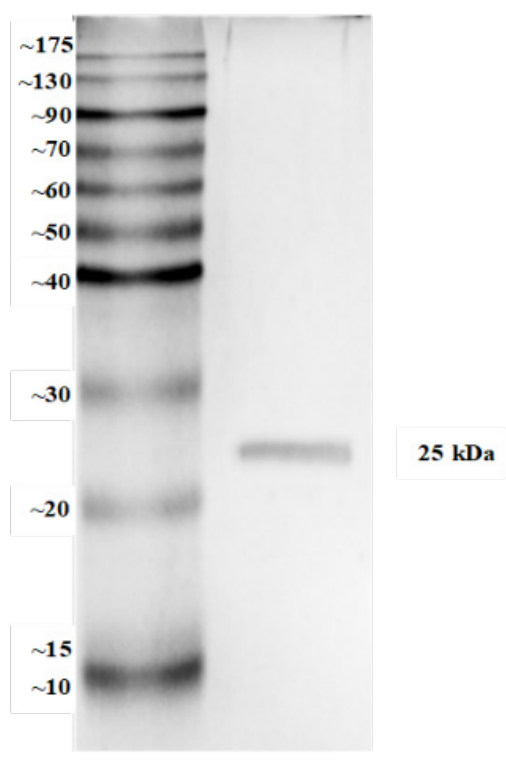

Figure 5 SDS-PAGE of purified lipase from Aspergillus oryzae ST11. 


\section{Characterization of purified lipase from Aspergillus oryzae ST11 \\ Effect of $\mathrm{pH}$ on activity and stability}

The purified $A$. oryzae ST11 lipase had an optimum pH for lipase activity at pH 7.5 (Figure 6(a)). This still gave lipase activity of more than $80 \%$ in the $\mathrm{pH}$ range between $6.5-8.0$ and was $58 \%$ at $\mathrm{pH}$ 9.0. The optimum $\mathrm{pH}$ for the activity of the purified lipase of $A$. oryzae studied by Toida et al. [27] was at $\mathrm{pH}$ 7.0. However, the optimum $\mathrm{pH}$ for the activity of the lipase from A. oryzae CJLU-31 was $\mathrm{pH} 4.0$, which was considered an acidic lipase [28]. For other Aspergillus species, A. fumigatus lipase had an optimum $\mathrm{pH}$ at 9.0 [14], and A. carneus lipase had an optimum $\mathrm{pH}$ at 8.5 [19], whereas $A$. niger lipase had an optimum $\mathrm{pH}$ at 7.0 [29]. It could be concluded that the lipase produced by Aspergillus species had a wide range of optimum $\mathrm{pH}$.

pH stability was the desired characteristic of enzyme application. After incubation of the purified lipase in a wide range of $\mathrm{pH}$ buffers, the purified $A$. oryzae ST11 lipase retained an activity of more than $80 \%$ in the buffers between $\mathrm{pH} 5.0$ - 8.0. The relative activity of purified lipase greatly decreased after incubation in buffer $\mathrm{pH}$ of lower than 5.0 and of higher than 8.0. In comparison, the activity of $A$. oryzae lipase was low at acidic $\mathrm{pH}$ and was stable in a $\mathrm{pH}$ range from $6.0-9.0$ at $25{ }^{\circ} \mathrm{C}$ [27]. Another report showed that the purified lipase from A. niger NCIM 1207 was stable at pH $8.0-11.0$ but retained activity at $10 \%$ in acidic $\mathrm{pH}[30]$.

\section{Effect of temperature on activity and stability}

Figure 6(b) shows the effect of temperature on the activity and stability of $A$. oryzae ST11 lipase. The purified lipase from $A$. oryzae ST11 showed an optimum temperature for lipase activity at $37^{\circ} \mathrm{C}$. The results showed that it still had high activity in a range of temperatures between 30 and $45^{\circ} \mathrm{C}$. However, when the temperature of the system was higher than $55^{\circ} \mathrm{C}$, the activity was decreased drastically and retained only $23 \%$ at $65{ }^{\circ} \mathrm{C}$.

For thermostability, after incubation of the purified lipase from $A$. oryzae $\mathrm{ST} 11$ at $30-65^{\circ} \mathrm{C}$ for $2 \mathrm{~h}$, the remaining activities of lipase at 30 and $37{ }^{\circ} \mathrm{C}$ were higher than $90 \%$. The thermal stability was decreased rapidly when the temperature was higher than $45{ }^{\circ} \mathrm{C}$, and the activity was $32 \%$ at $65{ }^{\circ} \mathrm{C}$. However, its stability was different from the lipase of $A$. oryzae studied by Toida et al. [27], which was stable at $30{ }^{\circ} \mathrm{C}$, but was greatly reduced at $40{ }^{\circ} \mathrm{C}$, with $10 \%$ of the original activity.

\section{Effect of metal ions}

Different metal ions were used to study the effect on the activity of the purified A. oryzae ST11 lipase, with concentrations at 1.0 and $10.0 \mathrm{mM}$ compared with the control of lipase solution in Tris- $\mathrm{HCl}$ buffer without the addition of metal ions (Table 2). The results showed that the activity of lipase was slightly enhanced when $\mathrm{Ca}^{2+}, \mathrm{K}^{+}$or $\mathrm{Mg}^{2+}(1.0 \mathrm{mM})$ was presented in the reaction mixture. However, when the concentration of metal ions was increased to $10.0 \mathrm{mM}$, only the addition of $\mathrm{Mg}^{2+}$ showed a significant enhancement of activity compared to other metal ions. The increase of lipase activity in the presence of $\mathrm{Mg}^{2+}$ was also supported by the report of other studies with the lipases from A. niger NRRL3 [31] and A. terreus var. africanus (CBS 130.55) [32]. However, the report of Toida et al. [27] showed the opposite effect; $\mathrm{Mg}^{2+}(10.0 \mathrm{mM})$ slightly decreased the lipase activity of $A$. oryzae. The lipase activity of A. oryzae ST11 was drastically suppressed by $\mathrm{Hg}^{2+}, \mathrm{Zn}^{2+}, \mathrm{Co}^{2+}$ and $\mathrm{Cu}^{2+}$ at both 1.0 and $10.0 \mathrm{mM}$. The negative effects of $\mathrm{Hg}^{2+}, \mathrm{Zn}^{2+}$ and $\mathrm{Cu}^{2+}$ were also reported in the study of other purified $A$. oryzae lipases $[27,32]$. The negative effects of $\mathrm{Zn}^{2+}$ and $\mathrm{Cu}^{2+}$ on lipase activity might be due to the interactions of those ions on the enzyme surface charge. It made the change of enzyme conformation, leading it to be less stable. As well as the effect of $\mathrm{Hg}^{2+}$, which had an inhibitory effect on the lipase activity with participation of the SH group in the enzyme structure, this indicates that thiol-containing amino acid residues might be important to enzymatic function [32,33]. 

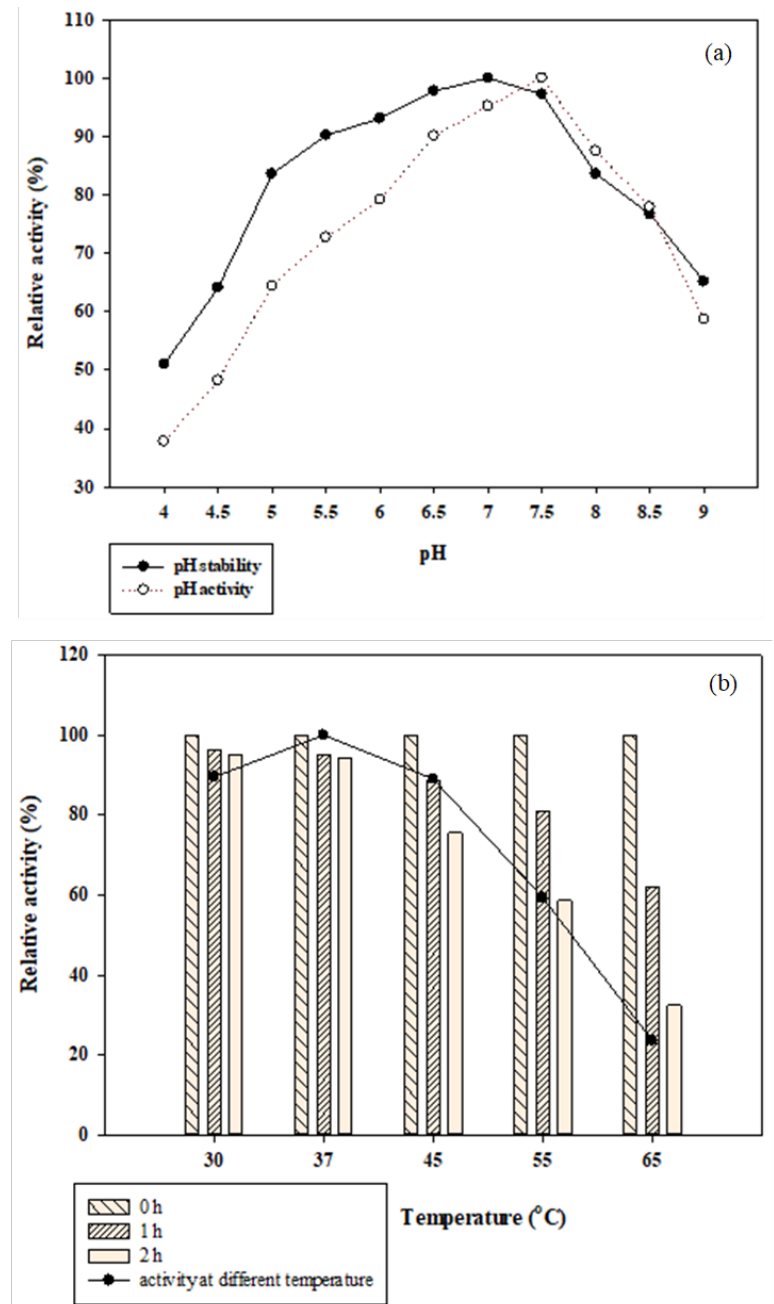

Figure 6 Effects of $\mathrm{pH}$ (a) and temperature (b) on the activity and stability of the purified lipase from Aspergillus oryzae ST11.

Table 2 Effect of metal ions on the stability of the purified Aspergillus oryzae ST11 lipase.

\begin{tabular}{ccc}
\hline Effect of metal ions & \multicolumn{2}{c}{ Relative activity (\%) } \\
\cline { 2 - 3 } & $\mathbf{1 . 0} \mathbf{~ m M}$ & $\mathbf{1 0 . 0} \mathbf{~ m M}$ \\
\hline $\mathrm{Control}^{*}$ & $100.0 \pm 4.5^{\mathrm{b}}$ & $100.0 \pm 4.5^{\mathrm{b}}$ \\
$\mathrm{FeCl}_{3}$ & $102.5 \pm 6.6^{\mathrm{ab}}$ & $83.5 \pm 8.0^{\mathrm{c}}$ \\
$\mathrm{CoCl}_{3}$ & $82.8 \pm 2.6^{\mathrm{c}}$ & $14.3 \pm 0.9^{\mathrm{h}}$ \\
$\mathrm{CuCl}_{2}$ & $32.5 \pm 5.4^{\mathrm{d}}$ & $33.5 \pm 4.4^{\mathrm{f}}$ \\
$\mathrm{MgCl}_{2}$ & $103.9 \pm 2.3^{\mathrm{ab}}$ & $122.7 \pm 1.4^{\mathrm{a}}$ \\
$\mathrm{HgCl}_{2}$ & $14.6 \pm 2.6^{\mathrm{e}}$ & $14.1 \pm 1.4^{\mathrm{h}}$ \\
$\mathrm{CaCl}_{2}$ & $109.3 \pm 1.2^{\mathrm{a}}$ & $66.7 \pm 1.4^{\mathrm{d}}$ \\
$\mathrm{ZnCl}_{2}$ & $18.7 \pm 0.3^{\mathrm{e}}$ & $19.4 \pm 1.6^{\mathrm{h}}$ \\
$\mathrm{KCl}$ & $106.3 \pm 1.9^{\mathrm{ab}}$ & $84.1 \pm 6.2^{\mathrm{c}}$ \\
$\mathrm{NaCl}^{\mathrm{AlCl}}$ & $101.9 \pm 1.3^{\mathrm{ab}}$ & $88.9 \pm 9.0^{\mathrm{c}}$ \\
\hline
\end{tabular}

*Lipase solution in $50 \mathrm{mM}$ Tris-HCl buffer $\mathrm{pH} 7.5$ without the addition of metal ions

\section{Effects of inhibitors and surfactants}

Many surfactants and inhibitors were investigated for their effects on the lipase activity of $A$. oryzae ST11. In general, surfactants are used to enhance the catalysis of lipase by increasing the lipid water 
interfacial area [2]. However, in this study, most surfactants showed a negative effect on the lipase activity of $A$. oryzae ST11 (Table 3). The negative effect of surfactants was observed in the presence of sodium dodecyl sulfate (SDS), Tween-80, Tween-20, and arabic gum with the activity of 21.1, 21.6, 23.7 and $72.1 \%$, respectively. Triton X-100 severely reduced the activity of the purified lipase, and the activity was retained at only $6 \%$. A reduction of lipase activity after the addition of surfactants also occurred in the study by Zhou et al. [28]. The activity of purified lipase from $A$. oryzae CJLU-31 was decreased in the presence of Tween-40, Tween-80, and SDS, and retained activity at 20.0, 11.0 and 22.0 $\%$, respectively [28]. Saxena et al. [19] found that anionic detergent, such as SDS, had a negative effect on lipase activity. The strong inhibitory effects of Tween-20 and Tween- 80 were most likely due to their competitive attaching to the lipase molecule or the change in protein conformation; this leads to the blocking of the active form of protein, which negatively influences lipase catalysis [18,34,35].

The inhibitors (EDTA, PMSF, and $\beta$-mercaptoethanol) were used for studying the effect on the lipase activity at 1.0 and $10.0 \mathrm{mM}$. There was no significant loss of the lipase activity of $A$. oryzae ST11 in the presence of these inhibitors (Table 3). The presence of $\beta$-mercaptoethanol showed a slight effect on lipase activity. This meant there was no disulfide bond in the structure of lipase. In the case of EDTA addition, the activity of $A$. oryzae ST11 lipase was slightly higher than that of the control condition. It also implied that purified $A$. oryzae ST11 lipase was a non-metalloenzyme [2]. The PMSF which was used as serine inhibitors did not reduce the A. oryzae ST11 lipase activity. A similar result was observed from the study of Toida et al. [27], which revealed a non-significant reduction of $A$. oryzae lipase activity after incubation with PMSF. However, PMSF affected negatively the activity of purified A. carneus lipase [19].

Table 3 Effects of surfactants and inhibitors on the stability of the purified Aspergillus oryzae ST11 lipase.

\begin{tabular}{cc}
\hline Effects of surfactants and inhibitors & Relative activity (\%) \\
\hline Control* & $100.0 \pm 0.02^{\mathrm{a}}$ \\
Surfactants & \\
Triton X-100 (1\%) & $6.0 \pm 0.5^{\mathrm{d}}$ \\
Tween-80 (1\%) & $21.6 \pm 9.8^{\mathrm{c}}$ \\
Tween-20 (1\%) & $23.7 \pm 1.0^{\mathrm{c}}$ \\
Gum Arabic (1\%) & $72.1 \pm 8.5^{\mathrm{b}}$ \\
SDS (1\%) & $21.1 \pm 4.7^{\mathrm{c}}$ \\
Inhibitors & $101.9 \pm 5.2^{\mathrm{a}}$ \\
EDTA (1.0 mM) & $92.3 \pm 1.6^{\mathrm{a}}$ \\
EDTA (10.0 mM) & $92.7 \pm 2.3^{\mathrm{a}}$ \\
$\beta$-mercaptoethanol (1.0 mM) & $92.5 \pm 2.9^{\mathrm{a}}$ \\
P-mercaptoethanol (10.0 mM) & $97.1 \pm 4.1^{\mathrm{a}}$ \\
\hline
\end{tabular}

* Lipase solution in $50 \mathrm{mM}$ Tris-HCl buffer $\mathrm{pH} 7.5$ without the addition of surfactants or inhibitors

\section{Effect of organic solvents}

The hydrolysis reaction catalyzed by lipases of water-insoluble substrates takes place at the interface. The use of organic solvents can encourage the hydrolysis reaction of water-insoluble substrates by the lipase [1]. Hence, the high stability and the activity of lipase in the solvent system are of concern for the application of the enzyme. Investigation of the organic solvent effect on the stability of the purified $A$. oryzae ST11 lipase was conducted. The different polar and non-polar organic solvents (polarity index 0.0 - 5.2) were studied (Table 4). The activity of purified lipase was decreased after $1 \mathrm{~h}$ of incubation in all organic solvents compared to the control condition containing $50 \mathrm{mM}$ Tris- $\mathrm{HCl}$ buffer $\mathrm{pH}$ 7.5. The highest relative activity was obtained in the presence of isooctane and hexane, which are hydrophobic solvents. The high stability of A. oryzae ST11 lipase in non-polar solvents was supported by the many reports showing that the lipase was stable in the presence of hydrophobic solvents, while the activity was reduced in systems containing polar solvents. This was caused by the promotion of hydrophilicity of the solvent, leading to the removal of water from enzyme molecules [36-39]. 
Table 4 Effects of organic solvents on the lipase activity of the purified Aspergillus oryzae ST11 lipase.

\begin{tabular}{ccc}
\hline Organic solvents (25 \%) & Polarity index & Relative activity (\%) \\
\hline Ethanol & 5.2 & $3.7 \pm 0.4^{\mathrm{i}}$ \\
Methanol & 5.1 & $2.6 \pm 1.1^{\mathrm{i}}$ \\
Acetone & 5.1 & $26.3 \pm 2.8^{\mathrm{f}}$ \\
Ethyl acetate & 4.4 & $48.0 \pm 2.1^{\mathrm{e}}$ \\
Isopropanol & 3.9 & $56.0 \pm 2.9^{\mathrm{d}}$ \\
Xylene & 2.5 & $13.3 \pm 1.1^{\mathrm{h}}$ \\
Toluene & 2.4 & $19.0 \pm 1.4^{\mathrm{g}}$ \\
Iso-Octane & 0.1 & $70.0 \pm 1.8^{\mathrm{b}}$ \\
Hexane & 0.1 & $62.0 \pm 2.8^{\mathrm{c}}$ \\
50 mM Tris-HCl buffer pH 7.5 & - & $100.0 \pm 3.5^{\mathrm{a}}$ \\
\hline
\end{tabular}

\section{Substrate specificity}

The different natural oils were tested to determine the substrate specificity of the purified $A$. oryzae ST11 lipase. The results are shown in Figure 7. A hydrolysis reaction using palm oil as a substrate was controlled as a base value at $100 \%$ relative activity, and was measured at $\mathrm{pH} 7.5$ and $37^{\circ} \mathrm{C}$. Among nine natural oils, it was found that olive oil showed the highest activity, at $110 \%$ relative activity higher than that of palm oil. The rice bran oil and coconut oil had relative activities of lipase of more than $70 \%$, followed by linseed oil, for which the activity was around $50 \%$. In contrast, sunflower oil, soybean oil, canola oil, and corn oil showed lower activities of below $40 \%$. Considering the fatty acid compositions in each type of oil, the substrate specificity of the lipase was enhanced when the content of C18:n in the oil increased corresponding to oleic acid (C18:1) content existing largely in olive oil [40]. Shu et al. [41] also studied the substrate specificity of natural oils on the activity of A. niger F044 lipase. The results showed that $A$. niger F044 lipase had a broad range utilization of oil, and that olive oil gave the highest relative activity, while the lowest relative activity was obtained from castor oil.

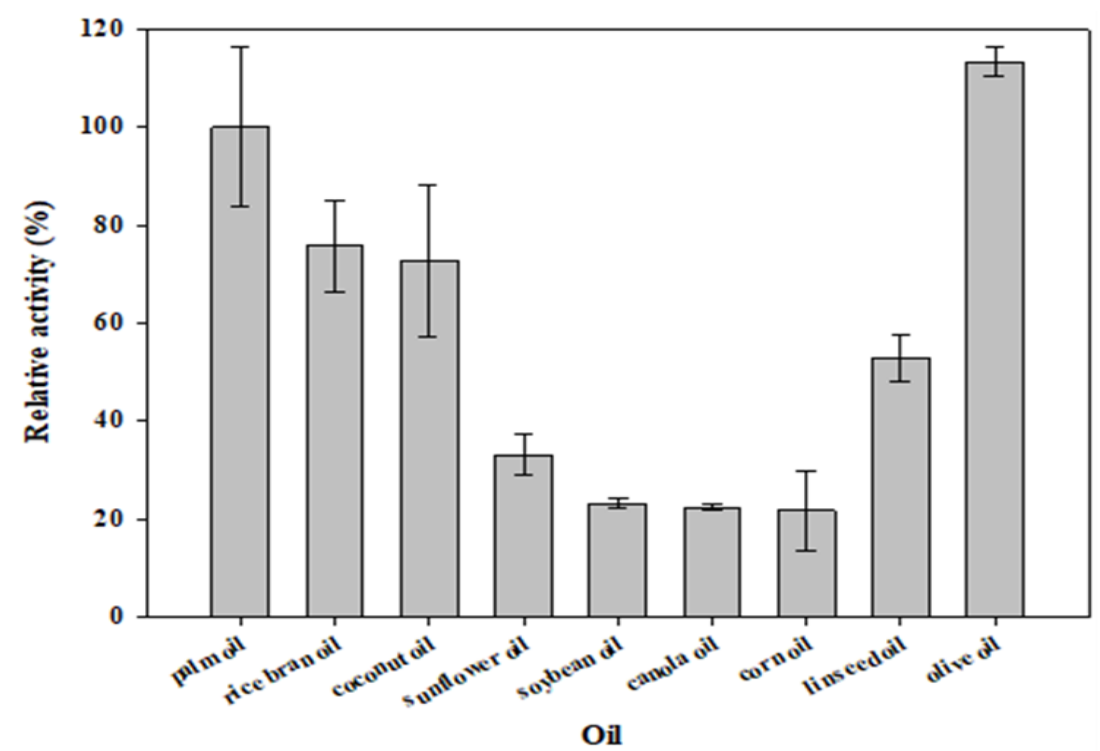

Figure 7 Effects of oil types on the activity of the purified lipase from Aspergillus oryzae ST11.

Biodiesel production catalyzed by concentrated $A$. oryzae ST11 lipase

Concentrated A. oryzae ST11 lipase was obtained from chilled acetone precipitation and used as a liquid enzyme for biodiesel conversion from palm oil and methanol. Figure 8 shows the highest biodiesel conversion (90\%) at $24 \mathrm{~h}$ with one-step addition of methanol ( 3 moles of methanol per 1 mole of palm oil). This result was obtained under the condition that water content in the system was $50 \%$ compared with the 
weight of palm oil in isooctane. Even though water was crucial for stabilizing the protein structure, the excess amount of water content from the lipase solution led to the presence of free fatty acid in the final product, which was caused by the promotion of hydrolysis reaction (Figure 9). The existence of free fatty acids in a system containing high water content was supported by the study of Andrade et al. [42] to produce biodiesel from Castor oil. The addition of water enhanced the biodiesel production providing the water-lipid phase for lipase catalysis. Water hydrolyzed the one mole of triglyceride into 3 moles of free fatty acid and 1 mole of glycerol. The 3-fatty acids were subsequently reacted with an alcohol to form biodiesel. However, increasing the water beyond the optimal point led to a negative effect on the biodiesel production, with the reverse reaction to break down the biodiesel molecule and gave a lower yield of biodiesel. Nevertheless, the suitable water content for biodiesel production might be different depending on the type and the condition of the reaction. Chen et al. [43] reported that biodiesel production from waste cooking oil using immobilized Candida lipase can be achieved at $91.08 \%$ with water content at $25 \%$, and that the yield of biodiesel was decreased when the water content applied to the system was higher than $25 \%$. In contrast, Baloch et al. [44] reported that biodiesel production from Jatropha oil by immobilized Magnusiomyces capitatus A4C extracellular lipase was enhanced when the water content was increased in the system, and it was achieved at $89.7 \%$ with water content at $100 \%$.

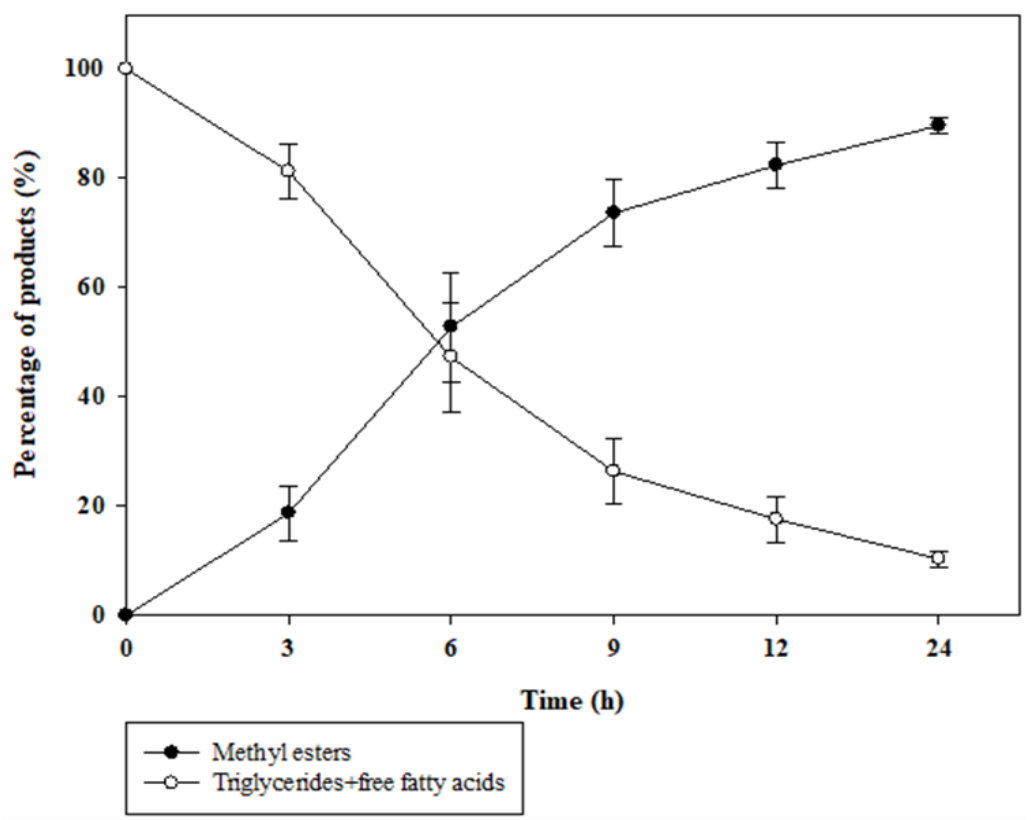

Figure 8 Time course of biodiesel production from palm oil catalyzed by concentrated A. oryzae ST11 lipase. The reaction mixture contained palm oil to methanol $(1: 3 \mathrm{~mol} / \mathrm{mol})$ and $100 \mu \mathrm{L}$ of the concentrated lipase. The reaction was carried out in a Thermomixer at $37^{\circ} \mathrm{C}$ and 1,200 rpm for $24 \mathrm{~h}$. 

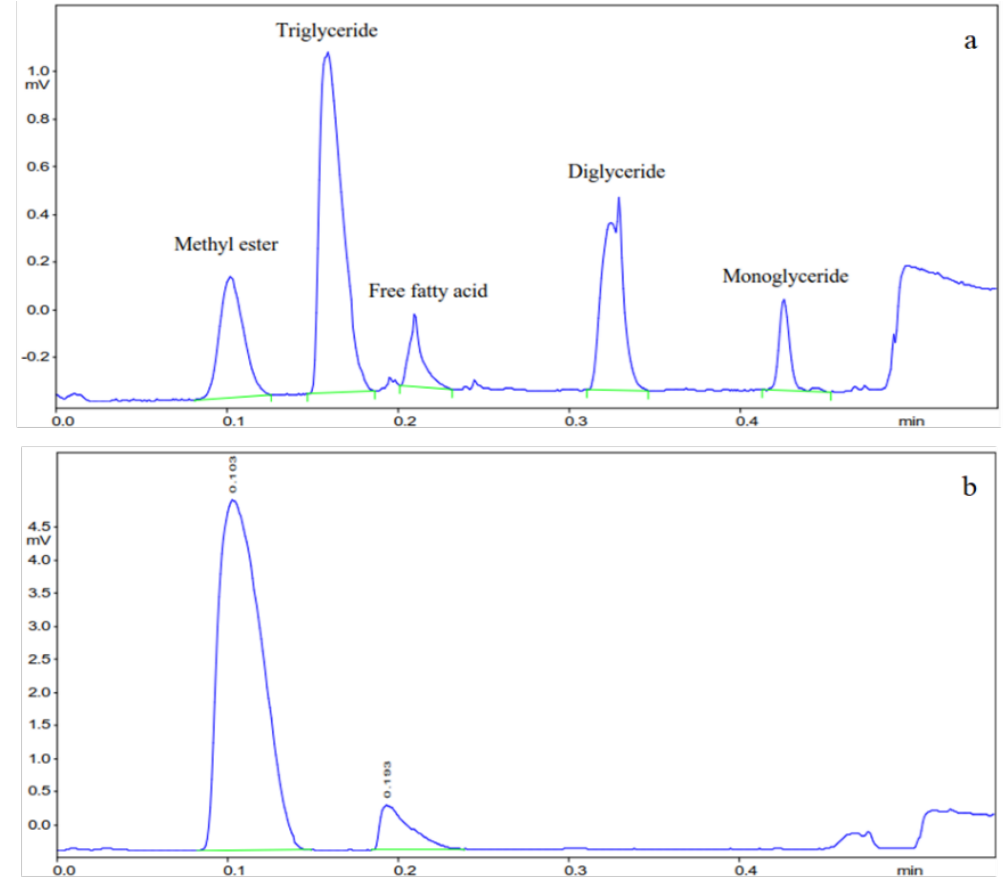

Figure 9 The transesterification profile analyzed by a TLC-FID analyzer with different standard compounds containing methyl ester, triglyceride, free fatty acid, diglyceride and monoglyceride, respectively (a) and the final product profile of transesterification reaction after $24 \mathrm{~h} \mathrm{(b).}$

\section{Conclusions}

The selected fungus was identified as Aspergillus oryzae ST11 and showed its capability to produce an extracellular lipase. This offered more flexibility of enzyme to be used in many industrial applications, compared with the use of whole-cell biocatalysts which might be limited in some applications. Moreover, the purified lipase from $A$. oryzae ST11 also presented the desired characteristics, with good stability at different $\mathrm{pH}$ and temperature. Even the use of the partially purified form of enzyme still had the ability to catalyze the transesterification reaction and yielded a high biodiesel conversion. Thus, these capabilities of lipase promise the biotechnological potential to be further studied and to be used in industrial applications.

\section{Acknowledgements}

This research was financially supported by the joint research fund between Prince of Songkla University and the Thailand Research Fund through the Royal Golden Jubilee Scholarship Ph.D. Program (Grant No. PHD/0321/2552).

\section{References}

[1] T Chaiyaso, P Seesuriyachan, W Zimmermann and A H-Kittikun. Purification and characterization of lipase from newly isolated Burkholderia multivorans PSU-AH130 and its application for biodiesel production. Ann. Microbiol. 2012; 62, 1615-24.

[2] $\mathrm{P}$ Ungcharoenwiwat and A H-Kittikun. Purification and characterization of lipase from Burkholderia sp. EQ3 isolated from wastewater from a canned fish factory and its application for the synthesis of wax esters. J. Mol. Catal. B Enzym. 2015; 115, 96-104.

[3] H Treichel, D de Oliveira, MA Mazutti, MD Luccio and JV Oliveira. A review on microbial lipases production. Food Bioprocess Tech. 2010; 3, 182-96.

[4] A Marini, N Imelio, G Picó, D Romanini and B Farruggia. Isolation of a Aspergillus niger lipase from a solid culture medium with aqueous two-phase systems. J. Chromatogr. B. 2011; 879, 2135-41.

[5] LN Nguyen, TT Dao, T Živković, M Fehrholz, W Schäfer and S Salomon. Enzymatic properties and expression patterns of five extracellular lipases of Fusarium graminearum in vitro. Enzyme Microb. Tech. 2010; 46, 479-86. 
[6] FJ Contesini, DB Lopes, GA Macedo, MDG Nascimento and PDO Carvalho. Aspergillus sp. lipase: Potential biocatalyst for industrial use. J. Mol. Catal. B. Enzym. 2010; 67, 163-71.

[7] K Geoffry and RN Achur. Screening and production of lipase from fungal organisms. Biocatal. Agr. Biotechnol. 2018; 14, 241-53.

[8] A Bajaj, P Lohan, PN Jha and R Mehrotra. Biodiesel production through lipase catalyzed transesterification: An overview. J. Mol. Catal. B Enzym. 2010; 62, 9-14.

[9] AK Singh and M Mukhopadhyay. Overview of fungal lipase: A review. Appl. Biochem. Biotechnol. 2012; 166, 486-52.

[10] OV Okoro, ZF Sun and EJ Birch. Lipases for biofuel production. In: R Aluko, EJ Birch, D Larsen, L Melton, M Rogers, F Shahidi, R Stadler, DS Waterhouse and P Varelis (Eds.). Encyclopedia of food chemistry. Elsevier, Amsterdam, 2018, p. 150-7.

[11] M Xiao, C Qi and JP Obbard. Biodiesel production using Aspergillus niger as a whole-cell biocatalyst in a packed-bed reactor. GCB Bioenerg. 2011; 3, 293-8.

[12] Z Li, X Li, Y Wang, F Wang and J Jiang. Expression and characterization of recombinant Rhizopus oryzae lipase for enzymatic biodiesel production. Bioresour. Tech. 2011; 102, 9810-13.

[13] Y Chen, BA Prior, G Shi and Z Wang. A rapid PCR-based approach for molecular identification of filamentous fungi. J. Microbiol. 2011; 49, 675-9.

[14] NA Zulkifli and L Zakaria. Morphological and molecular diversity of Aspergillus from corn grain used as livestock feed. HAYATI J. Biosci. 2017; 24, 26-34.

[15] JB Kantak, AV Bagade, SA Mahajan, SP Pawar and AA Prabhune. Isolation, identification and optimization of a new extracellular lipase producing strain of Rhizopus sp. Appl. Biochem. Biotechnol. 2011; 164, 969-78.

[16] K Durairaj, P Velmurugan, KA Vedhanayakisri, WS Chang, P Senthilkumar, KM Choi, JH Lee and BT Oh. Molecular and phenotypic characterization of pathogenic fungal strains isolated from ginseng root rot. Physiol. Mol. Plant Pathol. 2018; 104, 141-6.

[17] SM Basheer, S Chellappan, PS Beena, RK Sukumaran, KK Elyas and M Chandrasekaran. Lipase from marine Aspergillus awamori BTMFW032: Production, partial purification and application in oil effluent treatment. N. Biotechnol. 2011; 28, 627-38.

[18] A Mehta, C Grover and R Gupta. Purification of lipase from Aspergillus fumigatus using Octyl Sepharose column chromatography and its characterization. J. Basic Microbiol. 2018; 58, 857-66.

[19] RK Saxena, WS Davidson, A Sheoran, and B Giri. Purification and characterization of an alkaline thermostable lipase from Aspergillus carneus. Process Biochem. 2003; 39, 239-47.

[20] SY Lee and JS Rhee. Production and partial purification of a lipase from Pseudomonas putida 3SK. Enzym. Microb. Tech. 1993; 15, 617-23.

[21] P Ungcharoenwiwat, B Canyuk and A H-Kittikun. Synthesis of jatropha oil based wax esters using an immobilized lipase from Burkholderia sp. EQ3 and Lipozyme RM IM. Process Biochem. 2016; 51, 392-8.

[22] OH Lowry, NJ Rosebrough, AL Farr and RJ Randall. Protein measurement with the folin phenol reagent. J. Biol. Chem. 1951; 1, 265-75.

[23] N Rakchai, A H-Kittikun and W Zimmermann. Production of whole-cell lipase from Aspergillus nomius ST57 and optimization of methyl esters synthesis from palm oil in one step. Chiang Mai J. Sci. 2018; 45, 746-61.

[24] MA Innis, DH Gelfand, JJ Sninsky and TJ White. PCR protocols - a guide to methods and applications. Academic Press, California, 1990.

[25] TA Hall. BioEdit: A user-friendly biological sequence alignment editor and analysis program for Windows 95/98/NT. Nucleic Acids Symp. Ser. 1999; 41, 95-8.

[26] K Tamura, G Stecher, D Peterson, A Filipski and S Kumar. MEGA6: Molecular evolutionary genetics analysis version 6.0. Mol. Biol. Evol. 2013; 30, 2725-9.

[27] J Toida, K Kondoh, M Fukuzawa, K Ohnishi and J Sekiguchi. Purification and characterization of a lipase from Aspergillus oryzae. Biosci. Biotechnol. Biochem. 1995; 59, 1199-203.

[28] J Zhou, WW Chen, ZB Jia, GR Huang, Y Hong, JJ Tao and XB Luo. Purification and characterization of lipase produced by Aspergillus oryzae CJLU-31 isolated from waste cooking oily soil. Am. J. Food Tech. 2012; 7, 596-608.

[29] D Pokorny, A Cimerman and W Steiner. Aspergillus niger lipases: Induction, isolation and characterization of two lipases from a MZKI A116 strain. J. Mol. Catal. B Enzym. 1997; 2, 215-22.

[30] N Mhetras, S Patil and D Gokhale. Lipase of Aspergillus niger NCIM 1207: A potential biocatalyst for synthesis of isoamyl acetate. Indian J. Microbiol. 2010; 50, 432-7. 
[31] NZ Adham and EM Ahmed. Extracellular lipase of Aspergillus niger NRRL3; production, partial purification, and properties. Indian J. Microbiol. 2009, 49, 77-83.

[32] HS Hamdy and MA Abo-Tahon. Extracellular lipase of Aspergillus terreus var. africanus (CBS 130.55): Production, purification and characterisation. Ann. Microbiol. 2012; 62, 1723-36.

[33] Z Liu, Z Chi, L Wang and J Li. Production, purification and characterization of an extracellular lipase from Aureobasidium pullulans HN2.3 with potential application for the hydrolysis of edible oils. Biochem. Eng. J. 2008; 40, 445-51.

[34] S Sharma and SS Kanwar. Purification and bio-chemical characterization of a solvent-tolerant and highly thermostable lipase of Bacillus licheniformis strain SCD11501. Proc. Natl. Acad. Sci. India Sect. B. Biol. Sci. 2017; 87, 411-9.

[35] V Delorme, R Dhouib, S Canaan, F Fotiadu, F Carrière and JF Cavalier. Effects of surfactants on lipase structure, activity, and inhibition. Pharm. Res. 2011; 28, 1831-42.

[36] DS Dheeman, S Antony-Babu, JM Frías and GTM Henehan. Purification and characterization of an extracellular lipase from a novel strain Penicillium sp. DS-39 (DSM 23773). J. Mol. Catal. B. Enzym. 2011; 72, 256-62.

[37] B Ayaz, A Ugur and R Boran. Purification and characterization of organic solvent-tolerant lipase from Streptomyces sp. OC119-7 for biodiesel production. Biocatal. Agric. Biotechnol. 2015; 4, 103-8.

[38] A Hiol, MD Jonzo, N Rugani, D Druet, L Sarda and LC Comeau. Purification and characterization of an extracellular lipase from a thermophilic Rhizopus oryzae strain isolated from palm fruit. Enzyme Microb. Technol. 2000; 26, 421-30.

[39] B Venkatesagowda, E Ponugupaty, AM Barbosa-Dekker and RFH Dekker. Purification and characterization of lipases from Lasiodiplodia theobromae, and their immobilization and use for biodiesel production from coconut oil. Appl. Biochem. Biotechnol. 2018; 185, 619-40.

[40] BS Lakshmi, P Kangueane, B Abraham and G Pennathur. Effect of vegetable oils in the secretion of lipase from Candida rugosa (DSM 2031). Lett. Appl. Microbiol. 1999; 29, 66-70.

[41] ZY Shu, JK Yang and YJ Yan. Purification and characterization of a lipase from Aspergillus niger F044. Chin. J. Biotechnol. 2007; 23, 96-100.

[42] TA Andrade, M Errico and KV Christensen. Influence of the reaction conditions on the enzyme catalyzed transesterification of castor oil: A possible step in biodiesel production. Bioresour. Technol. 2017; 243, 366-74.

[43] Y Chen, B Xiao, J Chang, Y Fu, P Lv and X Wang. Synthesis of biodiesel from waste cooking oil using immobilized lipase in fixed bed reactor. Energy Convers. Manag. 2009; 50, 668-73.

[44] KA Baloch, A Upaichit and B Cheirsilp. Multilayered nano-entrapment of lipase through organicinorganic hybrid formation and the application in cost-effective biodiesel production. Appl. Biochem. Biotechnol. 2021; 193, 165-87. 